Article history :

\section{Medicinal importance of mushroom}

\section{Ravinder Kaur}

ABSTRACT : Nutritionally, mushrooms are low in energy and fat but high in protein, carbohydrate, and dietary fibre. Mushrooms contain a variety of minerals and trace elements such as potassium, and copper and vitamins such as riboflavin, niacin, and folates. They have been used as food for centuries because of their unique taste. Mushrooms are valuable resources for food, medicine and nutraceuticals. Now days, the people are more health conscious and focused on valuable food. This paper review focused on composition and medicinal importance of mushroom.

KEY WORDS : Mushroom, Cancer, Lipids

HOW TO CITE THIS ARTICLE : Kaur, Ravinder (2018). Medicinal importance of mushroom. Asian J. Hort.,13(2):64-67, DOI:10.15740/HAS/TAJH/13.2/64-67.Copyright@2018 : Hind Agri-Horticultural Society 